\title{
Escherichia coli 0157:H7 bacteriophage $\Phi 241$ isolated from an industrial cucumber fermentation at high acidity and salinity
}

\author{
Zhongjing $\mathrm{Lu}^{\mathbf{1}}{ }^{*}$ and Fred Breidt ${ }^{\mathbf{2}}$ \\ ' Department of Molecular and Cellular Biology, Kennesaw State University, Kennesaw, GA, USA \\ ${ }^{2}$ USDA Agricultural Research Service - Department of Food, Bioprocessing, and Nutrition Sciences, North Carolina State University, Raleigh, NC, USA
}

\section{Edited by:}

Javier Carballo, University of Vigo,

Spain

\section{Reviewed by:}

Catherine Maylin Loc-Carrillo,

University of Utah, USA

Zhao Chen, Clemson University, USA

\section{*Correspondence:}

Zhongjing Lu, Department of

Molecular and Cellular Biology, Kennesaw State University, 1000

Chastain Road, Kennesaw, GA 30144, USA

e-mail: jean_lu@kennesaw.edu
A novel phage, $\Phi 241$, specific for Escherichia coli $\mathrm{O} 157: \mathrm{H} 7$ was isolated from an industrial cucumber fermentation where both acidity $(\mathrm{pH} \leq 3.7)$ and salinity $(\geq 5 \% \mathrm{NaCl})$ were high. The phage belongs to the Myoviridae family. Its latent period was $15 \mathrm{~min}$ and average burst size was 53 phage particles per infected cell. The phage was able to lyse $48 \mathrm{E}$. coli 0157:H7 strains, but none of the 18 non-O157 strains (including E. coli O104:H7) or the $2 \mathrm{O}$ antigen-negative mutants of $\mathrm{O} 157: \mathrm{H} 7$ strain, 43895 $\Delta$ per (also lacking $\mathrm{H} 7$ antigen) and $\mathrm{F} 12$ (still expressing $\mathrm{H} 7$ antigen). However, the phage was able to lyse a per-complemented strain (43895 $\Delta$ perComp) which expresses 0157 antigen. These results indicated that phage $\Phi 241$ is specific for 0157 antigen, and E. coli strains lacking 0157 antigen were resistant to the phage infection, regardless of the presence or absence of $\mathrm{H} 7$ antigen. SDS-PAGE profile revealed at least 13 structural proteins of the phage. The phage DNA was resistant to many commonly used restriction endonucleases, suggesting the presence of modified nucleotides in the phage genome. At the multiplicity of infection of 10, 3, or 0.3 , the phage caused a rapid cell lysis within 1 or $2 \mathrm{~h}$, resulting in 3.5- or 4.5-log-unit reduction in cell concentration. The high lytic activity, specificity and tolerance to low $\mathrm{pH}$ and high salinity make phage $\Phi 241$ a potentially ideal biocontrol agent of $E$. coli $\mathrm{O} 157: \mathrm{H} 7$ in various foods. To our knowledge, this is the first report on E. coli O157:H7 phage isolated from high acidity and salinity environment.

\footnotetext{
Keywords: bacteriophage, phage $\Phi 241$, Escherichia coli 0157:H7, biocontrol agent, cucumber fermentation, high acidity and salinity, food safety
}

\section{INTRODUCTION}

Escherichia coli O157:H7 has emerged as one of the major foodborne pathogens. Each year, it causes more than 73,000 illnesses, 2,100 hospitalizations, and 60 deaths in the U.S. (Mead and Griffin, 1998; Mead et al., 1999; Rangel et al., 2005). A variety of foods have been associated with these outbreaks such as undercooked ground beef (Griffin and Tauxe, 1991; Anonymous, 1993, 2014; Bell et al., 1994), raw milk (Riley et al., 1983), cheese (Anonymous, 2010), bologna (Anonymous, 2011), cold sandwiches (Karmali, 1989), water (Swerdlow et al., 1992; Bopp et al., 2003), unpasteurized apple juice (Anonymous, 1996), sprouts, lettuce, spinach, and other vegetables (Como-Sebetti et al., 1997; Jinneman et al., 2003; Anonymous, 2006, 2012a,b, 2013). Healthy cattle are the primary reservoir of E. coli O157:H7. Human infection by E. coli O157:H7 can frequently be traced to the food or water contaminated with cattle manure (Gyles, 2007). The infection by this pathogen can result in severe hemorrhagic colitis and life-threatening hemolytic uremic syndrome (Remis et al., 1984; Cleary, 1988; Tarr, 1995; Nataro and Kaper, 1998). E. coli O157:H7 has a very low infectious dose (as low as 10 cells; Griffin and Tauxe, 1991; Griffin et al., 1994; Tuttle et al., 1999) partly due to its very efficient mechanisms of stress resistance (Price et al., 2004). Acid resistance is one of the characteristics of E. coli O157:H7. The bacterium has evolved multiple mechanisms to survive in low-pH environments (Lin et al., 1996; Castanie-Cornet et al., 1999; Jordan et al., 1999; Price et al., 2000, 2004; Large et al., 2005) such as gastrointestinal tracts and various acidic foods (Weagant et al., 1994; Diez-Gonzalez and Russell, 1999; Price et al., 2004). Acid resistance is especially crucial for food-borne pathogens that must survive the hostile acidic condition in the stomach before entering and colonizing the small intestines or colon (Berk et al., 2005; Chen and Jiang, 2014).

Acid adaptation can further enhance the survival of $E$. coli O157:H7 in fermented or acidified foods, and induce the crossprotection against heat, salt, and acids (Farber and Pagotto, 1992; Leyer and Johnson, 1993; Leyer et al., 1995; Cheville et al., 1996). A variety of acidic foods have been involved in the outbreaks caused by E. coli O157:H7. These include apple cider (Besser et al., 1993; Hilborn et al., 2000), unpasteurized apple juice (Cody et al., 1999), salami (Anonymous, 1995), and fermented sausage (Glass et al., 1992). E. coli O157:H7 can also tolerate high concentration of $\mathrm{NaCl}$ (Glass et al., 1992).

Many physical, chemical, and biological methods (such as pasteurization, radiation, addition of preservatives, or addition of lactic acid bacteria) have been used to control E. coli O157:H7 in foods. However, these control methods are not very effective for certain foods or they can alter the color, flavor, or texture of the foods. Safe and effective alternative methods are needed to control E. coli O157:H7 in foods. Recent studies have showed that the use 
of phages to control pathogenic bacteria in foods is a promising novel strategy.

The use of phages as antibacterial agents has several advantages over traditional antibacterial methods. First of all, phages are highly host specific. They only infect specific bacterial hosts and cause rapid bacterial lysis. They do not infect humans and other eukaryotes. Phages specific for pathogenic bacteria do not disrupt normal microflora in humans (Kudva et al., 1999) or in animals. Secondly, phages are not toxic to humans. Although certain cell lysis may release endotoxins, phages themselves do not generate any toxic products during their multiplication (Hagens and Loessner, 2010). Thirdly, phages do not alter food quality because they do not produce any substances that can change the taste, composition, aroma, or color of foods. In addition, phages are stable (Coffey et al., 2010), but also self-limiting in foods. They do not replicate unless their bacterial hosts are present (Hagens and Loessner, 2010). Moreover, phages are the most abundant biological entities and naturally present in the environment and a wide variety of foods (Guenther et al., 2009). It is relatively easy to isolate phages from the environment and propagate them in laboratories. All these features make phages promising novel biocontrol agents of bacterial pathogens in foods.

Recent studies have shown high efficacy of using phages against several major food-borne pathogens including E. coli O157:H7, Listeria monocytogenes, and Salmonella enterica in food products or on food contact surfaces. Use of phages specific for E. coli $\mathrm{O} 157: \mathrm{H} 7$ resulted in significant, log-unit reductions in E. coli O157:H7 counts in a variety of foods such as tomato, spinach, broccoli, and ground beef (Abuladze et al., 2008), beef (Carter et al., 2012), cantaloupe (Sharma et al., 2009), lettuce (Sharma etal., 2009; Ferguson etal., 2013), and other leafy green vegetables (Viazis et al., 2011). Such reductions could substantially decrease a risk of food-borne infections by the pathogen.

Significant progress in phage research for food safety has been made toward phage applications in foods. Several phagebased food additives have been recently approved or cleared by the U.S. Food and Drug Administration (FDA). These approvals have increased the impetus of phage research to uncover phage-mediated applications against other food-borne pathogens (Mahony et al., 2011). It is likely that more phage products will be developed and gradually gain market acceptance by the food industry and the consumers as a means of a safe, natural, and effective prevention of food-borne diseases (O'Flaherty et al., 2009; Sharma, 2013).

Phages specific for E. coli O157 have previously been isolated from human fecal materials or animal manures from bovine, ovine, swine, and chicken (Kudva etal., 1999; Morita et al., 2002; O'Flynn etal., 2004; Tomat etal., 2013), lake or pond water (Shahrbabak et al., 2013), and sewage (Sheng et al., 2006; Shahrbabak et al., 2013). No E. coli O157-specific phages were isolated from the environment where both acidity and salinity are high. The objectives of this study were to isolate an E. coli O157:H7-specific phage from a cucumber fermentation with low $\mathrm{pH}(3.7)$ and high salt concentration $(5 \% \mathrm{NaCl})$, to characterize the phage, and to evaluate the potential of the phage as an effective biocontrol agent against E. coli O157:H7 in various foods.

\section{MATERIALS AND METHODS BACTERIAL STRAINS AND CULTURE CONDITIONS}

The E. coli strains used in this study are listed in Tables $\mathbf{1}$ and 2. A total of 46 E. coli O157:H7 strains, and 18 E. coli nonO157:H7 strains from various sources were obtained from the culture collection of USDA Agricultural Research Service located at North Carolina State University. The non-O157 strains included a variety of $E$. coli strains that express a variety of $\mathrm{H}$ antigens including $\mathrm{H} 7$ antigen. Two previously described $\mathrm{O}$ antigennegative mutants (43895 $\Delta$ per and F12), one per-complemented mutant (43895 $\Delta$ perComp), and two E. coli O157:H7 parent strains (ATCC 43895 and 8624) were kindly provided by Pina Fratamico (Table 3). All strains were stored in tryptic soy broth (TSB; Difco) supplemented with $16 \%$ (v/v) glycerol at $-80^{\circ} \mathrm{C}$ until use. Fresh overnight culture of each E. coli strain was prepared by inoculating $10 \mathrm{ml}$ of TSB with an isolated colony from a tryptic soy agar (TSA) plate and incubating statically for $12 \mathrm{~h}$ at $37^{\circ} \mathrm{C}$. For phage lysate preparation, TSB broth was supplemented with $10 \mathrm{mM} \mathrm{CaCl}_{2}$ (Sigma-Aldrich, St. Louis, MO, USA) unless otherwise stated. Soft TSA agar used in plaque assay was prepared with TSB broth supplemented with $0.6 \%$ agar.

\section{BRINE SAMPLE COLLECTION AND TREATMENT}

To isolate E. coli O157:H7-specific phages, brine samples $(40 \mathrm{ml}$ each) were taken from seven industrial cucumber fermentation tanks (capacity: 32,000 1) from a commercial processing plant. The tanks contained approximately $55 \%$ pickling cucumbers in 5 to $8 \%$ recycled $\mathrm{NaCl}$ brine, prepared essentially as described by Breidt et al. (2013). These samples were taken during the fermentation (3-5 days after the tanks were packed and brined). Samples were transported to the laboratory at ambient temperature $\left(\sim 23^{\circ} \mathrm{C}\right)$, stored at $4^{\circ} \mathrm{C}$, and processed within $24 \mathrm{~h}$. The $\mathrm{pH}$ of each brine sample was measured and adjusted to around 6.4 with $5 \mathrm{M} \mathrm{NaOH}$. The $\mathrm{pH}$-adjusted brine samples were then centrifuged $(5,000 \times g$ for $10 \mathrm{~min})$. The supernatants were filtered through syringe filters $(0.45 \mu \mathrm{m}$ pore size $)$ to remove cellular materials and solid particles. The filtrates were stored at $4^{\circ} \mathrm{C}$ until used as potential phage source for phage isolation.

\section{PHAGE ISOLATION}

Ten E. coli O157:H7 strains (shown in bold text, Table 1) were used as potential hosts for phage isolation. Overnight cultures of these $\mathrm{O} 157$ strains $\left(\sim 10^{9} \mathrm{CFU} / \mathrm{ml}\right)$ were prepared in TSB. A 96well microplate was used to enrich phages potentially present in the filtered brines. Each well of the microplate contained $200 \mu \mathrm{l}$ of TSB, $5 \mu \mathrm{l}$ of one of the $10 \mathrm{E}$. coli O157:H7 strains and $45 \mu \mathrm{l}$ of one of the eight filtered brines, so the eight wells in the same column received the same O157:H7 strain. The first 10 wells in the same row received the same filtered brine. After incubation at $37^{\circ} \mathrm{C}$ for $20 \mathrm{~h}$, the microplate was centrifuged ( $\mathrm{SH}-3000$ rotor, RC-5B centrifuge, Sorvall, Newtown, CT, USA) at $4,000 \mathrm{rpm}, 4^{\circ} \mathrm{C}$ for $20 \mathrm{~min}$. The supernatant (lysate) in each well was collected and used in spot tests to detect the presence of phages. Each spot test was performed by adding $10 \mu \mathrm{l}$ of a phage lysate onto a lawn of E. coli O157:H7 in a soft agar overlay on a TSA plate. After 


\begin{tabular}{|c|c|c|}
\hline$I^{a}$ & Serotype & Source \\
\hline B0201b & 0157:H7 & Apple cider outbreak \\
\hline В0349 & O157:H7 & Spinach outbreak \\
\hline B0264 & O157:H7 & Apple juice outbreak, 1996 \\
\hline B0204 & O157:H7 & Pork \\
\hline B0202 & O157:H7 & Salami outbreak \\
\hline B0203 & O157:H7 & Ground beef \\
\hline B0348 & O157:H7 & Salami \\
\hline B0350 & O157:H7 & Sakai \\
\hline B0243 & O157:H7 & Bovine carcass \\
\hline B0242 & O157:H7 & Bovine carcass \\
\hline B0240 & O157:H7 & Bovine carcass \\
\hline B0239 & O157:H7 & Bovine carcass \\
\hline B0238 & O157:H7 & Bovine carcass \\
\hline B0241 & O157:H7 & Bovine carcass \\
\hline B0258 & O157:H7 & Bovine feces \\
\hline B0259 & O157:H7 & Bovine feces \\
\hline B0301 & O157:H7 & Water \\
\hline B0307 & O157:H7 & Water \\
\hline B0306 & O157:H7 & Water \\
\hline B0309 & O157:H7 & Water \\
\hline B0302 & O157:H7 & Water \\
\hline B0297 & O157:H7 & Water \\
\hline B0299 & O157:H7 & Water \\
\hline B0285 & O157:H7 & Water \\
\hline B0275 & O157:H7 & Water \\
\hline B0305 & O157:H7 & Water \\
\hline B0281 & O157:H7 & Water \\
\hline B0289 & O157:H7 & Water \\
\hline B0280 & O157:H7 & Water \\
\hline B0287 & O157:H7 & Water \\
\hline B0283 & O157:H7 & Water \\
\hline B0269 & O157:H7 & Human, outbreak, 2000, waterborne \\
\hline B0273 & O157:H7 & Human, outbreak, 2002, leafy vegetable \\
\hline B0247 & O157:H7 & Human, outbreak \\
\hline B0296 & O157:H7 & Human, outbreak, 2005, leafy vegetable \\
\hline B0311 & O157:H7 & Human, outbreak, 2006, leafy vegetable \\
\hline B0246 & O157:H7 & Human, outbreak \\
\hline B0271 & O157:H7 & Human, outbreak, 2003, leafy vegetable \\
\hline B0250 & O157:H7 & Human, outbreak \\
\hline B0263 & O157:H7 & Human, sporadic, 1997, \\
\hline B0251 & O157:H7 & Human, outbreak \\
\hline B0249 & O157:H7 & Human, outbreak \\
\hline B0266 & O157:H7 & Human, outbreak, 1999, taco meat \\
\hline B0245 & O157:H7 & Human, outbreak \\
\hline B0265 & O157:H7 & Human, outbreak, 1999, lettuce \\
\hline B0244 & O157:H7 & Human, outbreak \\
\hline
\end{tabular}

a $I D$, identification number in the culture collection of USDA-ARS Food Fermentation Laboratory.

bThe strains with ID bolded were used for initial phage isolation.
Table 2 | Non-0157 strains of $E$. coli that are resistant to phage $\$ 241$.

\begin{tabular}{lll}
\hline ID $^{\mathbf{a}}$ & Serotype & Source \\
\hline B0445 & O26:H11 & Human \\
B0449 & O26:H11 & Human \\
B0463 & O103:H6 & Human diarrea \\
B0460 & O103:H25 & Human \\
B0469 & O104:H4 & Human \\
B0467 & O104:H21 & Human, milk outbreak \\
B0475 & O111:NM ${ }^{b}$ & Human \\
B0478 & O111:H8 & Human \\
B0479 & O121:NM & Human diarrhea \\
B0485 & O145:NM & Human \\
B0457 & O45:H2 & Cow (calf) \\
B0468 & O104:H7 & Ground beef \\
B0235 & Non-O157c & Bovine feces \\
B0237 & Non-O157 & Bovine feces \\
B0234 & Non-O157 & Bovine feces \\
B0236 & Non-O157 & Bovine feces \\
B0233 & Non-O157 & Bovine feces \\
25922 & O6:H1 & ATCC \\
\hline
\end{tabular}

${ }^{a} D$, identification number.

${ }^{\mathrm{b}} \mathrm{NM}$, non-motile.

${ }^{\mathrm{C}}$ The strains were not completely serotyped. But the data showed that they did not respond to the serum antibody against 0157 strains.

${ }^{\mathrm{d}}$ ATCC, American Type Culture Collection.

overnight incubation at $37^{\circ} \mathrm{C}$, the plates were checked for a zone of bacterial lysis.

\section{PHAGE PURIFICATION AND CONCENTRATION}

Phage from a positive spot-test plate was purified and concentrated using the methods described by Lu et al. (2003) with minor modification. Briefly, an isolated single plaque was picked and propagated against its natural host in TSB at $37^{\circ} \mathrm{C}$. After two runs of plaque purification, the phage lysate was prepared and then centrifuged at 5,000 $\times g$ for $10 \mathrm{~min}$. The supernatant was filtered through bottle-top filter $(0.45 \mu \mathrm{m}$ pore size). The filtered high titer phage stock (typically ca. $10^{10} \mathrm{PFU} / \mathrm{ml}$ ) was stored at $4^{\circ} \mathrm{C}$. To further purify and concentrate the phage, a portion of the phage stock were treated with DNase I and RNase A, and then concentrated by PEG precipitation. The concentrated phage was further purified by $\mathrm{CsCl}$ step density gradient ultracentrifugation at $600,000 \times \mathrm{g}$ for $6 \mathrm{~h}$ at $4^{\circ} \mathrm{C}$ followed by dialysis as described by Lu et al. (2003). The ultracentrifuge-purified phage was used for electron microscopy analysis, SDS-PAGE, and DNA extraction.

\section{ELECTRON MICROSCOPY}

Phage samples were negatively stained with $2 \%(\mathrm{w} / \mathrm{v})$ aqueous uranyl acetate $(\mathrm{pH} 4)$ on carbon-coated grids and examined by transmission electron microscopy (JEM 1200EX TEM, JEOL) at an accelerating voltage of $80 \mathrm{kV}$. Electron micrographs were taken at a magnification of 50,000× (Center for Electron Microscopy, North Carolina State University, Raleigh, NC, USA). 
Table 3 | Phage susceptibility of E. coli 0157:H7 strains and their $\mathrm{O}$ antigen-negative mutants.

\begin{tabular}{|c|c|c|c|}
\hline E. coli strain & Description & Plaque formation ${ }^{a}$ & Source or reference \\
\hline ATCC 43895 & Wild-type E. coli O157: $\mathrm{H} 7$, clinical isolate, $\mathrm{stx}_{1}{ }^{+} / \mathrm{stx}_{2}{ }^{+}$ & + & ATCC $^{b}$ \\
\hline $43895 \Delta$ perComp & $43895 \Delta$ per transformed with $\mathrm{pCR} \|:: \mathrm{per}$ & + & Sheng et al. (2008) \\
\hline 8624 & Wild-type E. coli O157: $\mathrm{H} 7$, clinical isolate, $\mathrm{stx}_{1} / \mathrm{stx}_{2}{ }^{+}$ & + & Bilge et al. (1996) \\
\hline F12 & O antigen-negative mutant of strain 8624 & - & Bilge et al. (1996) \\
\hline
\end{tabular}

$a_{+}$, susceptible to $\Phi 241 ;-$, not susceptible to $\Phi 241$.

b ATCC, American Type Culture Collection.

\section{ONE-STEP GROWTH KINETICS}

One step growth experiments were carried out based on the method described by Leuschner et al. (1993) and Foschino et al. (1995) with some modifications. Briefly, the experiment started at a multiplicity of infection (MOI) of 0.01 in a $15-\mathrm{ml}$ tube containing the phage (approximately $1 \times 10^{6} \mathrm{PFU} / \mathrm{ml}$ ) and its natural host O157:H7 strain B0241 in $10 \mathrm{ml}$ TSB. After incubation in a water bath at $37^{\circ} \mathrm{C}$ for $10 \mathrm{~min}$ (to allow phage adsorption), the tube was centrifuged at $13,000 \times g$ for $30 \mathrm{~s}$. The supernatant was removed and subjected to plaque assay to determine the titer of the un-absorbed phage. The pellet containing (partially) infected cells was immediately re-suspended in $10 \mathrm{ml}$ of pre-warmed TSB. After taking the first sample, the tube was returned to the water bath $\left(37^{\circ} \mathrm{C}\right)$. A sample $(100 \mu \mathrm{l})$ was collected every $5 \mathrm{~min}$ (up to $60 \mathrm{~min}$ ). Each sample was immediately diluted and subjected to plaque assay. All assays were carried out in triplicate. The experiment was repeated three times. Latent period was defined as the time interval between the end of the adsorption and the beginning of the first burst, as indicated by the initial rise in phage titer (Ellis and Delbruck, 1939; Adams, 1959). Burst size was calculated as the ratio of the final number of liberated phage particles to the initial number of infected bacterial cells during the latent period (Adams, 1959).

\section{HOST RANGE}

Phage $\Phi 241$ was the only phage isolated from one of the seven samples. The host range of $\Phi 241$ was determined by spot tests against 46 E. coli O157:H7 strains (Table 1) and 18 non-O157 strains (Table 2 ) on TSA. In each test, $10 \mu \mathrm{l}$ of high titer phage stock $\left(10^{10} \mathrm{PFU} / \mathrm{ml}\right)$ was used to spot a bacterial lawn of a strain on a plate. Each test was done in duplicate. The $\mathrm{O}$ antigen-negative mutants of E. coli O157:H7 and their parent strains (Table 3) were also tested using the agar overlay method.

\section{PHAGE STRUCTURAL PROTEINS}

The phage structural proteins were analyzed using the method previously described by Lu etal. (2003) with some modifications. Briefly, the ultracentrifuge-purified phage particles were mixed with SDS-PAGE sample buffer and then heated in a boiling water bath for $10 \mathrm{~min}$. The boiled sample was loaded onto a NuPAGE precast gradient minigel (4-12\% Bis-Tris, Invitrogen Corporation, Carlsbad, CA, USA). Electrophoresis was carried out at $75 \mathrm{~V}$ for $2 \mathrm{~h}$. Pre-stained protein standard (Invitrogen) was used to estimate the molecular weights of the proteins. The gel was stained with SimplyBlue SafeStain (Invitrogen).

\section{PHAGE DNA EXTRACTION AND RESTRICTION}

Phage DNA was prepared from the concentrated lysate using the phenol-chloroform extraction method as described by Lu et al. (2003), and digested with restriction endonucleases (AluI, BamHI, ClaI, EcoRI, EcoRV, HindIII, MspI, SwaI, and XbaI; New England BioLabs, Beverly, MA, USA) according to the manufacturer's instructions. The resulting DNA fragments were separated on the $1 \%$ agarose gel containing $0.001 \%$ SYBR Safe DNA gel stain (Invitrogen) by gel electrophoresis in Tris-borate-EDTA buffer at $70 \mathrm{~V}$ for $2 \mathrm{~h}$. The $1 \mathrm{~kb}$ DNA ladder (Promega, Madison, WI, USA) was used to estimate the size of the digested phage DNA.

\section{PHAGE INFECTION}

The lytic activity of phage $\Phi 241$ against host E. coli O157:H7 B0241 was investigated in TSB medium at three different MOIs. A bacterial overnight culture was diluted with TSB to a concentration of ca. $9 \times 10^{6} \mathrm{CFU} / \mathrm{ml}$. Ten milliliter of the diluted bacterial culture was then transferred into each of the four 15-ml tubes. One of these tubes served as a control. To each of other three tubes, a high titer phage stock $\left(2.8 \times 10^{10} \mathrm{PFU} / \mathrm{ml}\right)$ was added to achieve an initial MOI of 10,3 , or 0.3 , respectively. The four tubes were incubated statically at $37^{\circ} \mathrm{C}$. Samples were taken from each tube at 60 -min intervals for a 12 -h period. After serial dilution, each sample was plated onto TSA plates using a spiral autoplater (Model 4000, Spiral Biotech, Bethesda, MD, USA). The plates were incubated at $37^{\circ} \mathrm{C}$ overnight. The colonies on each plate were enumerated using Q-Count system (Model 510, Spiral Biotech, Norwood, MA, USA). The experiment was repeated two more times.

\section{STATISTICAL ANALYSIS}

Differences in bacterial cell concentration between various grouping of MOIs were analyzed by using one-way analysis of variance (ANOVA) and Tukey's multiple comparison.

\section{RESULTS AND DISCUSSION ISOLATION OF PHAGE $\Phi 241$}

Seven brine samples from 32,000-1 cucumber fermentation tanks (all from the same commercial plant) were enriched for phage isolation. One sample was found to contain a phage that infects $E$. coli O157:H7. The phage-containing sample was taken from a tank 
3 days after the tank was packed with size 2 A cucumbers $(\sim 27-$ $32 \mathrm{~mm}$ in diameter). The $\mathrm{pH}$ and the salt $(\mathrm{NaCl})$ concentration of the sample were 3.7 and $5 \%$, respectively. In contrast, the $\mathrm{pH}$ and salt concentration of the samples from other six tanks were in the range of $3.42-3.92$, and 6 to $8 \%$, respectively. The higher salinity in these six tanks may greatly inhibit phages, which may explain why no O157:H7 phages were isolated from them. The isolated O157:H7 phage was designated $\Phi 241$. The presence of phage $\Phi 241$ specifically active against $E$. coli O157:H7 in an early stage of the commercial cucumber fermentation indicates that the host strain(s) may be present as well. The most likely source for $E$. coli $\mathrm{O} 157: \mathrm{H7}$ in the commercial fermentation would be the fresh cucumbers. Application of animal waste as fertilizer and irrigation of crops with waste water have been recognized as important routes through which E. coli O157:H7 can contaminate fresh vegetables during primary production (Ongeng et al., 2013). However, we are unaware of any reports of disease outbreaks caused by vegetative pathogens from fermented vegetables. Previous research has shown that E. coli O157:H7 will be killed during fermentation of cucumbers in a $\mathrm{pH}$ and time dependent manner (Breidt and Caldwell, 2011).

The isolated phage $\Phi 241$ forms small (ca. $1 \mathrm{~mm}$ in diameter) plaques on the lawn of its natural host, E. coli O157:H7 strain B0241 which contains stx2 gene and was originally isolated from bovine carcass (Table 1). The concentration of high-titer phage stock (ca. $10^{10} \mathrm{PFU} / \mathrm{ml}$ ) remained unchanged during 2 years of storage at a refrigeration temperature, indicating that the phage is very stable.

\section{MORPHOLOGY}

The electron micrograph (Figure 1) showed that phage $\Phi 241$ has an icosahedral head (about $80 \mathrm{~nm}$ in diameter) and a contractile tail (ca. $33 \mathrm{~nm}$ long in the contracted state) with a base plate and several tail fibers. The overall morphology of $\Phi 241$ indicates that it is a T4-like phage, belonging to the Myoviridae family of the Caudovirales order. Interestingly, several phage particles appeared to cluster together through the tail fibers (Figure 1). The base plate and tail fibers are usually involved in the host cell recognition and receptor-binding by many tailed phages (Riede, 1987; Leiman et al., 2004; Bartual et al., 2010; Garcia-Doval and van Raaij, 2012).

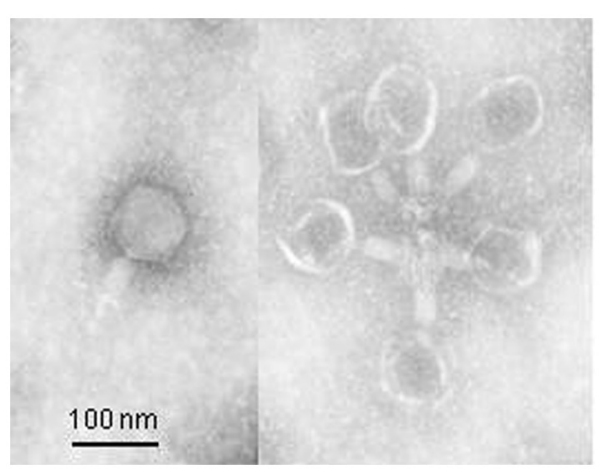

FIGURE 1 | Transmission electron micrograph of phage $\mathbf{\Phi 2 4 1}$ negatively stained with $\mathbf{2} \%$ uranyl acetate (pH 4). Scale bar, $100 \mathrm{~nm}$.

\section{ONE-STEP GROWTH KINETICS}

Figure 2 shows the one-step growth of phage $\Phi 241$. The latent period was only $15 \mathrm{~min}$ (excluding $10 \mathrm{~min}$ for adsorption), which is shorter than the typical latent periods (21-120 $\mathrm{min}$ ) for most Myoviridae phages. A short latent period allows phage $\Phi 241$ to replicate faster than most Myoviridae phages. The average burst size of $\Phi 241$ was about 53 phage particles per infected cell, which is in the range of 50-100 PFU/cell for many Myoviridae phages (Foschino et al., 1995; Chang et al., 2005; Raya et al., 2006; Bao et al., 2011; Park et al., 2012). A few Myoviridae phages have very large burst sizes. The burst size of phage PhaxI (another O157:H7 phage) is $420 \mathrm{PFU}$ per cell (Shahrbabak et al., 2013). A phage with both a short latent period (15 min or less) and a large burst size (>50 PFU/cell) may have a selective advantage over competing phages, resulting in very high lytic activity (Park et al., 2012).

\section{HOST RANGE}

A total of 69 E. coli strains from various sources (Tables 1-3) were tested to determine the host range of phage $\Phi 241$. The phage was able to lyse all 46 O157:H7 strains (Table 1), but none of the 18 non-O157 strains (Table 2) including O104:H7 strain which has the same $\mathrm{H}$ antigen as that of $\mathrm{O} 157: \mathrm{H7}$. E. coli O104:H7 was originally isolated from ground beef (Bosilevac and Koohmaraie, 2011). It is also Shiga toxin-producing strain containing two uncommon Shiga toxin gene variants, st $x_{1 \mathrm{c}}$ and $s t x_{2 \mathrm{c}}$ (Bosilevac and Koohmaraie, 2011). The data suggested that the phage is $\mathrm{O} 157$ antigen specific, and $\mathrm{H} 7$ antigen may not be involved in the host recognition and binding. Phage infection requires specific receptors on bacterial cells. The common receptors on $E$. coli include $\mathrm{O}$ antigen of lipopolysaccharide (LPS), outer membrane proteins, pili, fimbriae, and flagella $(\mathrm{H})$ antigen (Topley and Wilson, 1990; Bokete et al., 1997). Many cell wall receptors can be shared by different bacterial strains and serotypes (Topley and Wilson, 1990). To confirm that O157 antigen (not H7 antigen) serves as the receptor during $\Phi 241$ adsorption, two previously described $\mathrm{O}$ antigen-negative mutants (43895 $\Delta$ per and F12), one per-complemented mutant (43895 $\Delta$ perComp), and two E. coli O157:H7 parent strains (ATCC 43895 and 8624) were

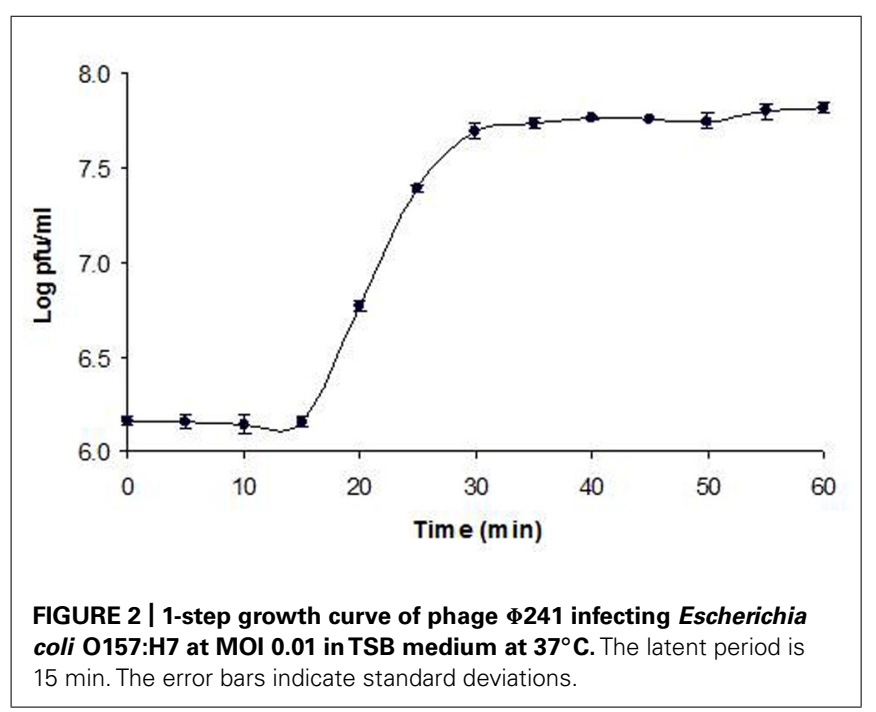


tested for their susceptibility to $\Phi 241$ infection (Table 3). The mutant $43895 \Delta$ per was generated by deletion of a putative perosamine synthetase gene (per) in the $r f b$ gene cluster (Sheng et al., 2008). The mutant F12 was created by transposon insertion of TnphoA in the per gene (Bilge et al., 1996). Deletion of per gene or insertion in per gene resulted in a mutant lacking the $\mathrm{O}$ antigen. The $\Delta$ per mutant $(43895 \Delta$ per) also lacked $\mathrm{H} 7$ antigen, but the transposon insertion mutant (F12) still expressed the H7 antigen. The per-complemented mutant (43895 $\Delta$ perComp) was constructed by cloning per in the E. coli vector pCRII and transforming pCRII::per into the mutant to restore O157 antigenicity (Sheng et al., 2008). Table 3 showed that phage $\Phi 241$ lysed the two O157:H7 parent strains (ATCC 43895 and 8624) which had the full-length $\mathrm{O} 157$ antigen, and the per-complemented strain (43895 $\Delta$ perComp) which was able to express O157 antigen. But the phage did not lyse the two $\mathrm{O} 157$ antigen-negative mutants, 43895 $\Delta$ per (also lacking H7 antigen) and F12 (still having $\mathrm{H} 7$ antigen). These results supported our hypothesis that O157 antigen is required for the infection by phage $\Phi 241$, and strains lacking $\mathrm{O} 157$ antigen were resistant to the phage infection, regardless of the presence or absence of $\mathrm{H} 7$ antigen in the strains. Similar observations have been reported for other O157specific phages. Kudva et al. (1999) studied three O157-specific phages isolated from bovine and ovine fecal samples. They found that the three phages lysed all of the eight tested E. coli O157 strains including the strain 8624 and did not lyse non-O157 E. coli strains, or O157-negative mutants including F12. In addition, the three phages did not lyse the complement of the O157-deficient mutant, F12(pF12), which produces a truncated O157 LPS (Kudva et al., 1999). They found that phage infection and plaque formation were influenced by the structure of the host cell O157 LPS. Strains that did not express the O157 antigen or expressed a truncated LPS were not susceptible to plaque formation or lysis by phage. Interestingly, strains that expressed abundant mid-rangemolecular-weight LPS were lysed in broth media but did not support plaque formation. They explained that in broth media, the excess mid-range-molecular-weight LPS can diffuse from cells into the broth. But on soft agar, those molecules may accumulate around cells, thereby preventing phage attachment (Kudva et al., 1999). An appropriate length of the O side chains and an optimal LPS concentration may be necessary to make the receptor available for phage interaction and/or to allow irreversible phage binding (Calendar, 1988). The high specificity of phage $\Phi 241$ for O157 antigen makes it an ideal biocontrol agent of E. coli O157:H7 without disrupting the beneficial bacteria such as probiotics in foods, normal flora in humans, or other microflora in cattle.

\section{STRUCTURAL PROTEINS}

SDS-PAGE gel revealed at least 13 protein bands from $\Phi 241$ (Figure 3), indicating that the phage contains many types of structural proteins. Four of the protein bands are in the molecular weight (MW) range of 26 to $50 \mathrm{kDa}$. These include three weak bands and one strong band (band 7 in Figure 3, MW $\approx 44 \mathrm{kDa}$ ). In fact, this strong band is the strongest one among all bands, indicating that the protein in this band is the most abundant protein. In many tailed phages, the most abundant proteins are

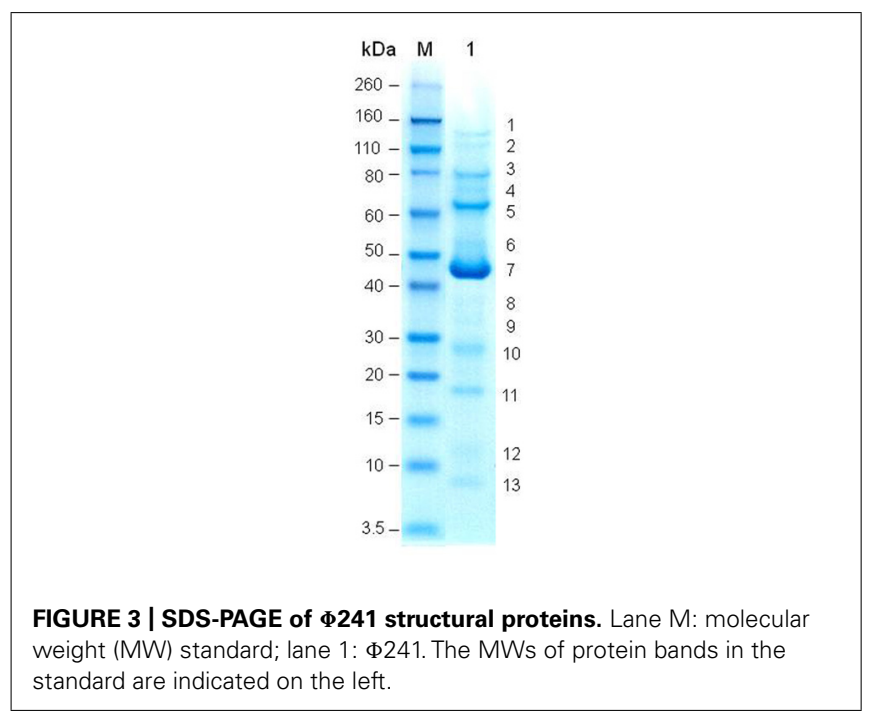

usually identified as the major head proteins (Santos et al., 2011). The MWs of major head proteins generally fall within the range of 26-50 kDa. For example, the sequence-predicted MWs of the major capsid protein in Lactobacillus plantarum phage $\Phi J \mathrm{~L}-1$ ( $\mathrm{Lu}$ et al., 2005), O157:H7 phage PhaxI (Shahrbabak et al., 2013), Pseudomonas aeruginosa phages LKA1 and LKD16 (Ceyssens et al., 2006), Salmonella enterica phage PVP-SE1 (Santos et al., 2011) are 30.4, 48.0, 36.7, 37.7, and 38.5 kDa, respectively. Since SDSPAGE analysis can only reveal a very limited number of structural proteins, genomic studies are needed in order to better understand phage structural proteins and their functions.

\section{DNA RESTRICTION}

The $\Phi 241$ genome could be digested by rare-cutters, AluI, MspI, and SwaI (Figure 4). Restriction by AluI or MspI generated more

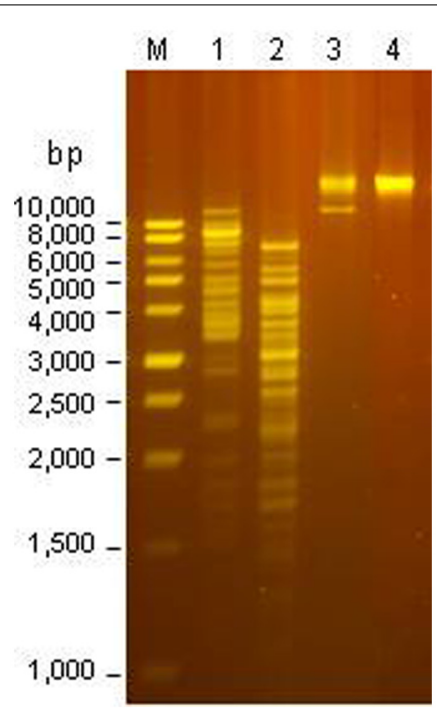

FIGURE 4 | Restriction analysis of the DNA from $\mathbf{9 2 4 1 . ~ L a n e ~ M : ~ 1 - k b ~}$ ladder; Lane 1: digestion by Alul; lane 2: digestion by Mspl; lane 3: digestion by Swal; lane 4: undigested DNA. 
than 15 bands on agarose gel while restriction by SwaI only generated a single band with a high MW. The phage genome could not be digested by many commonly used restriction endonucleases such as BamHI, ClaI, EcoRI, EcoRV, HindIII, and XbaI. Similar phenomenon was also observed for other O157:H7-specific phages. Shahrbabak et al. (2013) reported that the genome of phage PhaxI was resistant to eight tested restriction endonucleases including BamHI, EcoRI, EcoRV, HindIII, and a few others (Shahrbabak et al., 2013). The resistance suggested the presence of modification such as methylation and glycosylation in the phage DNA, allowing the phage to evade the restriction by the host enzymes (Bickle and Kruger, 1993; Nechaev and Severinov, 2008; Vasu and Nagaraja, 2013). Sequence analysis may provide insight into the anti-restriction modification system in phage genome.

\section{PHAGE INFECTION}

The lytic activity of phage $\Phi 241$ against its natural host E. coli O157:H7 B0241 was investigated at three different MOIs. Figure 5 shows the growth curves of phage-free and phage-infected cultures in TSB medium at $37^{\circ} \mathrm{C}$. The phage-free culture (the control culture) grew steadily during the first $4 \mathrm{~h}$ of incubation. After $4 \mathrm{~h}$, the control culture entered the stationary phase and remained unchanged (Figure 5). In contrast, the phage infection at the MOI of 3 or 10 caused a rapid cell lysis within $1 \mathrm{~h}$, resulting in 3- or 4.5-log decrease in the cell concentration. Such a high lytic activity within $1 \mathrm{~h}$ may be attributed in part to the short latent period (15 $\mathrm{min}$ ) of the phage. During the second hour, the cell concentration of the culture with a MOI of 3 continued to decrease while the cell concentration of the culture with the MOI of 10 started to increase. In contrast, infection at the MOI of 0.3 initially caused a slow cell lysis (less than 0.5 -log reduction) during the first hour, but a rapid cell lysis (3-log reduction) during the second hour. The data from statistical analysis showed

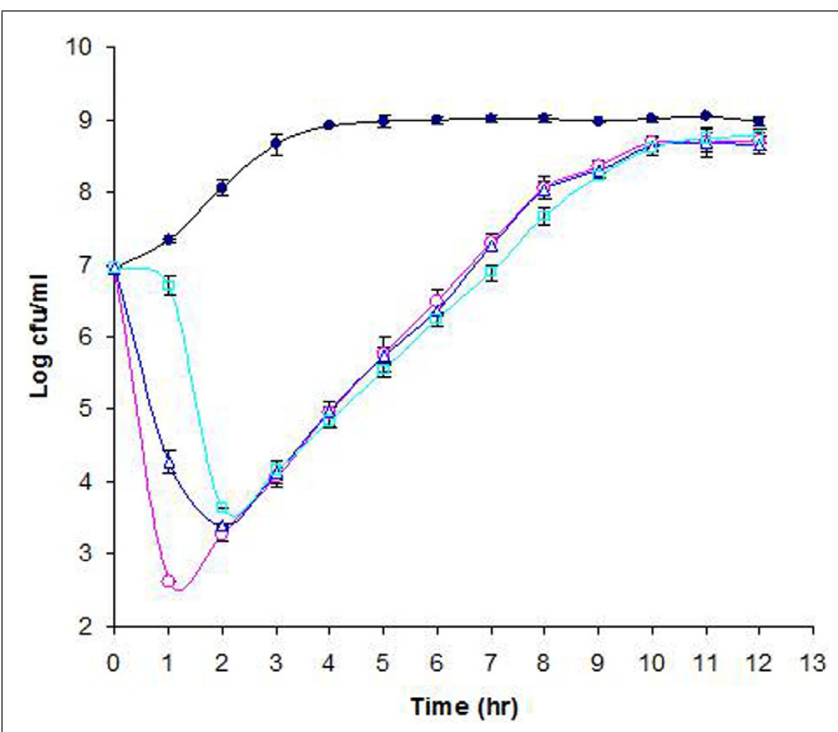

FIGURE 5 | Lytic activity of phage $\Phi 241$ against $E$. coli 0157:H7 in TSB medium at MOI $10(0), 3(\Delta)$, or $0.3(\square)$. The control (•) contains only E. coli $0157: \mathrm{H7}$. All cultures were incubated at $37^{\circ} \mathrm{C}$. The error bars indicate standard deviations in triplicate experiments. that at $1 \mathrm{~h}$ after phage infection the cell concentrations from different MOIs were statistically different $(\mathrm{P}<0.05)$ and every cell concentration was different from all other cell concentrations $(\alpha=0.05)$. At $2 \mathrm{~h}$ after phage infection the cell concentration from the MOI of 0.3 was statistically different from all other cell concentrations while the cell concentrations from the initial MOIs of 3 and 10 were not statistically different. Similar rapid cell lysis caused by $\Phi 241$ in cucumber juice was also observed (preliminary data not shown). Kudva et al. (1999) evaluated the lytic activity of three O157-specific phages in Luria-Bertani medium supplemented with $5 \mathrm{mM} \mathrm{MgSO}_{4}$ at $37^{\circ} \mathrm{C}$. They reported that the significant $(>4 \mathrm{log}$ ) decrease in E. coli O157:H7 concentration caused by those phages individually or in cocktail required much higher MOI $\left(10^{3} \mathrm{PFU} / \mathrm{CFU}\right)$ and much longer incubation time $(8 \mathrm{~h})$ compared with those in our study. Figure 5 showed that the cultures with an initial MOI of 3 or 0.3 started to grow after $2 \mathrm{~h}$. Interestingly, after $3 \mathrm{~h}$ of infection, all three phage-infected cultures, regardless of the initial MOI, reached the same cell concentration $\left(10^{4} \mathrm{CFU} / \mathrm{ml}\right)$, which was $4.5-\log$ lower than that of the control and 3-log lower than the initial cell concentration. As the incubation continued, the three cultures continued to grow at a similar rate, gradually approaching to the cell concentration of the control. After $12 \mathrm{~h}$ of infection, the phage titers in the cultures at the initial MOI of 10, 3, and 0.3 reached $4 \times 10^{9}, 5 \times 10^{9}$, and $1.6 \times 10^{10} \mathrm{PFU} / \mathrm{ml}$, respectively. Apparently, the culture started with the lowest initial MOI $(0.3)$ contained the highest phage titer $\left(1.6 \times 10^{10} \mathrm{PFU} / \mathrm{ml}\right)$ at the end of incubation.

The growth of phage-infected cultures after 1 or $2 \mathrm{~h}$ of infection indicated that phage-resistant mutants had emerged. The emergence of phage-resistant mutants during phage infection has been reported by many other studies (Kudva et al., 1999; O'Flynn et al., 2004; Park etal., 2012; Tomat et al., 2013). Phage resistance may result from mutation that alters cell surface receptors, restriction modification, or abortive infection associated with the presence of clustered regularly interspaced short palindromic repeats (CRISPRs) in the bacterial genome (Hill, 1993; Hashemolhosseini et al., 1994; Allison and Klaenhammer, 1998; Barrangou et al., 2007). A few studies found that certain phage resistant mutants of E. coli O157:H7 had altered OmpC expression or lost OmpC, suggesting the involvement of the major outer membrane protein in phage attachment (Yu et al., 2000; Morita et al., 2002; Mizoguchi et al., 2003). Some studies found that cell morphology and colony morphology of phage-resistant mutants differed greatly from those of the parent E. coli O157:H7 strains (Mizoguchi et al., 2003; O'Flynn etal., 2004). Phage-resistant mutant cells appeared coccoid and smaller. As a result, phage-resistant culture could not reach the same turbidity as that of the parent strain culture (O'Flynn et al., 2004). The frequency of phage-resistant mutation is generally around $10^{-6} \mathrm{CFU}$ for E. coli O157:H7 (O’Flynn et al., 2004; Park et al., 2012; Tomat et al., 2013). With such a low mutation frequency and the low level of E. coli O157:H7 typically encountered in foods, phage resistance should not hinder the use of phages as biocontrol agents against the pathogenic bacteria (O'Flynn et al., 2004; Tanji et al., 2004). Some studies explored the potential of using a phage cocktail to minimize the development of phage resistant mutants on meats and other foods 
(O’Flynn et al., 2004; Tanji et al., 2004; Carter et al., 2012; Tomat et al., 2013). Using a phage cocktail containing different phages against the same bacterial species can decrease the likelihood of selecting phage-resistant mutants. Because different phages may attach to different receptors on the host, mutations in one phage receptor gene may not alter the mutant's susceptibility to another phage that attaches to a different receptor on the bacterial cells (Tanji et al., 2004).

In conclusion, phage $\Phi 241$ is highly specific for E. coli O157:H7 and very stable when stored at high titers at refrigeration temperature. The phage causes rapid cell lysis, and tolerates both low $\mathrm{pH}$ and high salinity. These features indicate that the phage has a high potential as an effective biocontrol agent of E. coli O157:H7 in foods. Trials are under way to evaluate the efficacy of the phage to control E. coli O157:H7 in various foods including acidic and/or salty foods. To our knowledge, this is the first report on the E. coli $\mathrm{O} 157: \mathrm{H} 7$ phage isolated from low $\mathrm{pH}$ and high salinity environment.

\section{ACKNOWLEDGMENTS}

We thank Ms. Lisa Moeller (Fermenting Solutions International, LLC, Mt. Olive, NC, USA) for help with the brine samples taken from commercial cucumber fermentation tanks for this study. We also thank Pina Fratamico (the Agricultural Research Service, the U. S. Department of Agriculture, Wyndmoor, PA, USA) for providing several bacterial strains and Sandra Parker for excellent secretarial assistance.

\section{REFERENCES}

Abuladze, T., Li, M., Menetrez, M. Y., Dean, T., Senecal, A., and Sulakvelidze, A. (2008). Bacteriophages reduce experimental contamination of hard surfaces, tomato, spinach, broccoli, and ground beef by Escherichia coli O157:H7. Appl. Environ. Microbiol. 74, 6230-6238. doi: 10.1128/AEM.01465-08

Adams, M. H. (1959). Bacteriophage. New York: Interscience Publishers, Inc.

Allison, G. E., and Klaenhammer, T. R. (1998). Phage resistance mechanisms in lactic acid bacteria. Int. Dairy J. 8, 207-226. doi: 10.1016/S0958-6946(98)00043-0

Anonymous. (1993). Update: multistate outbreak of Escherichia coli O157:H7 infections from hamburgers-Western United States, 1992-1993. Morb. Mortal. Wkly. Rep. 42, 258-263.

Anonymous. (1995). Escherichia coli O157:H7 outbreak linked to commercially distributed dry-cured salami. Morb. Mortal. Wkly. Rep. 44, 157-160.

Anonymous. (1996). Outbreak of Escherichia coli O157:H7 infections associated with drinking unpasteurized commercial apple juice-British Columbia, California, Colorado, and Washington, October 1996. Morb. Mortal. Wkly. Rep. 45, 975.

Anonymous. (2006). Ongoing multistate outbreak of Escherichia coli serotype O157:H7 infections associated with consumption of fresh spinach-United States, September 2006. Morb. Mortal. Wkly. Rep. 55, 1045-1046.

Anonymous. (2010). Investigation Update: Multistate Outbreak of E. coli O157:H7 Infections Associated with Cheese. Available at: http://www.cdc.gov/ecoli/2010/ch eese0157/index.html [accessed January 17, 2015].

Anonymous. (2011). Investigation Announcement: Multistate Outbreak of E. coli O157:H7 Infections Associated with Lebanon Bologna. Available at: http://www.cdc.gov/ecoli/2011/O157_0311/index.html [accessed January 17, 2015].

Anonymous. (2012a). Investigation Announcement: Multistate Outbreak of E. coli O157:H7 Infections Linked to Romaine Lettuce. Available at: http://www.cdc.gov/ecoli/2011/ecoliO157/romainelettuce/120711/index.html [accessed October 26, 2012].

Anonymous. (2012b). Multistate Outbreak of Shiga Toxin-producing Escherichia coli O157:H7 Infections Linked to Organic Spinach and Spring Mix Blend (Final Update). Available at: http://www.cdc.gov/ecoli/2012/O157H7-11-12/index.html [accessed January 17, 2015].
Anonymous. (2013). Multistate Outbreak of Shiga toxin-producing Escherichia coli O157:H7 Infections Linked to Ready-to-Eat Salads (Final Update). Available at: http://www.cdc.gov/ecoli/2013/O157H7-11-13/index.html [accessed January 17, 2015].

Anonymous. (2014). Multistate Outbreak of Shiga toxin-producing Escherichia coli O157:H7 Infections Linked to Ground Beef (Final Update). Available at: http://www.cdc.gov/ecoli/2014/O157H7-05-14/index.html [accessed January 17, 2015].

Bao, H., Zhang, H., and Wang, R. (2011). Isolation and characterization of bacteriophages of Salmonella enterica serovar Pullorum. Poultry Sci. 90, 2370-2377. doi: 10.3382/ps.2011-01496

Barrangou, R., Fremaux, C., Deveau, H., Richards, M., Boyaval, P., Moineau, S., et al. (2007). CRISPR provides acquired resistance against viruses in prokaryotes. Science 315, 1709-1712. doi: 10.1126/science. 1138140

Bartual, S. G., Otero, J. M., Garcia-Doval, C., Llamas-Saiz, A. L., Kahn, R., Fox, G. C., et al. (2010). Structure of the bacteriophage T4 long tail fiber receptor-binding tip. Proc. Natl. Acad. Sci. U.S.A. 107, 20287-20292. doi: 10.1073/pnas.10112 18107

Bell, B. P., Goldoft, M., Griffin, P. M., Davis, M. A., Gordon, D. C., Tarr, P. I., et al. (1994). A multistate outbreak of Escherichia coli O157:H7-associ-ated bloody diarrhea and hemolytic uremic syndrome from hamburgers: the Washington experience. JAMA 272, 1349-1353. doi: 10.1001/jama.1994.035201700 59036

Berk, P. A., de Jonge, R., Zwietering, M. H., Abee, T., and Kieboom, J. (2005). Acid resistance variability among isolates of Salmonella enterica serovar Typhimurium DT 104. J. Appl. Microbiol. 99, 859-866. doi: 10.1111/j.1365-2672.2005.0 2658.x

Besser, R. E., Lett, S. M., Weber, J. T., Doyle, M. P., Barrett, T. J., Wells, J. E., et al. (1993). An outbreak of diarrhea and hemolytic uremic syndrome from Escherichia coli O157:H7 in fresh-pressed apple cider. JAMA 269, 2217-2220. doi: 10.1001/jama.1993.03500170047032

Bickle, T. A., and Kruger, D. H. (1993). Biology of DNA restriction. Microbiol. Rev. 57, 434-450.

Bilge, S. S., Vary, J. C., Dowell, S. F., and Tarr, P. I. (1996). Role of the Escherichia coli O157:H7 O side chain in adherence and analysis of an rfb locus. Infect. Immun. 64, 4795-4801.

Bokete, T. N., Whittam, T. S., Wilson, A. W., Clausen, C. R., O'Callahan, C. M., Moseley, S. L., et al. (1997). Genetic and phenotypic analysis of Escherichia coli with enteropathogenic characteristics isolated from Seattle children. J. Infect. Dis. 175, 1382-1389. doi: 10.1086/516470

Bopp, D. J., Sauders, B. D., Waring, A. L., Ackelsberg, J., Dumas, N., BraunHowland, E., et al. (2003). Detection, isolation, and molecular subtyping of Escherichia coli $\mathrm{O} 157: \mathrm{H} 7$ and Campylobacter jejuni associated with a large waterborne outbreak. J. Clin. Microbiol. 41, 174-180. doi: 10.1128/JCM.41.1.174-18 0.2003

Bosilevac, J. M., and Koohmaraie, M. (2011). Prevalence and characterization of non-O157 Shiga toxin-producing Escherichia coli isolated from commercial ground beef in the United States. Appl. Environ. Microbiol. 77, 2103-2112. doi: 10.1128/AEM.02833-10

Breidt, F., and Caldwell, J. M. (2011). Survival of Escherichia coli O157:H7 in cucumber fermentation brines. J. Food Sci. 76, M198-M203. doi: 10.1111/j.17503841.2011.02045.x

Breidt, F., McFeeters, R. F., Pérez-Díaz, I., and Lee, C. H. (2013). "Fermented vegetables," in Food Microbiology: Fundamentals and Frontiers, 4th Edn, eds M. P. Doyle and L. R. Beuchat (Washington, DC: ASM Press), 841-855.

Calendar, R. (ed.). (1988). The Bacteriophages, Vol. 1. New York: Plenum Press.

Carter, C., Parks, A., Abuladze, T., Li, M., Woolfson, J., Magnone, J., et al. (2012). Bacteriophage cocktail significantly reduces Escherichia coli O157:H7 contamination of lettuce and beef, but does not protect against recontamination. Bacteriophage 2, 178-185. doi: 10.4161/bact.22825

Castanie-Cornet, M. P., Penfound, T. A., Smith, D., Elliott, J. F., and Foster, J. W. (1999). Control of acid resistance in Escherichia coli. J. Bacteriol. 181, 3525-3535.

Ceyssens, P. J., Lavigne, R., Mattheus, W., Chibeu, A., Hertveldt, K., Mast, J., et al. (2006). Genomic analysis of Pseudomonas aeruginosa phages LKD16 and LKA1: establishment of the $\Phi \mathrm{KMV}$ subgroup within the T7 supergroup. J. Bacteriol. 188, 6924-6931. doi: 10.1128/JB.00831-06

Chang, H. C., Chen, C. R., Lin, J. W., Shen, G. H., Chang, K. M., Tseng, Y. H., et al. (2005). Isolation and characterization of novel giant Stenotrophomonas 
maltophilia phage ФSMA5. Appl. Environ. Microbiol. 71, 1387-1393. doi: 10.1128/AEM.71.3.1387-1393.2005

Chen, Z., and Jiang, X. (2014). Microbiological safety of chicken litter or chicken litter-based organic fertilizers: a review. Agriculture 4, 1-29. doi: 10.3390/agriculture4010001

Cheville, A. M., Arnold, K. W., Buchrieser, C., Cheng, C. M., and Kaspar, C. W. (1996). rpoS regulation of acid, heat, and salt tolerance in Escherichia coli O157:H7. Appl. Environ. Microbiol. 62, 1822-1824.

Cleary, T. G. (1988). Cytotoxin producing Escherichia coli and the hemolytic uremic syndrome. Pediatr. Clin. N. Am. 35, 458-501.

Cody, S. H., Glynn, M. K., Farrar, J. A., Cairns, K. L., Griffin, P. M., Kobayashi, J., et al. (1999). An outbreak of Escherichia coli O157:H7 infection from unpasteurized commercial apple juice. Annu. Intern. Med. 130, 202-209. doi: 10.7326/00034819-130-3-199902020-00005

Coffey, B., Mills, S., Coffey, A., McAuliffe, O., and Ross, R. P. (2010). Phage and their lysins as biocontrol agents for food safety applications. Annu. Rev. Food Sci. Technol. 1, 449-468. doi: 10.1146/annurev.food.102308.124046

Como-Sebetti, K., Reagan, K. S., Alaire, S., Parrott, K., Simonds, C. M., Hrabowy, S., et al. (1997). Outbreaks of Escherichia coli O157:H7 infection associated with eating alfalfa sprouts- Michigan and Virginia, June-July 1997. Morb. Mortal. Wkly. Rep. 46, 741-744.

Diez-Gonzalez, F., and Russell, J. B. (1999). Factors affecting the extreme acid resistance of Escherichia coli O157:H7. Food Microbiol. 16, 367-374. doi: 10.1006/fmic.1998.0249

Ellis, E. L., and Delbruck, M. (1939). The growth of bacteriophage. J. Gen. Physiol. 22, 365-384. doi: 10.1085/jgp.22.3.365

Farber, J. M., and Pagotto, F. (1992). The effect of acid shock on the heat resistance of Listeria monocytogenes. Lett. Appl. Microbiol. 15, 197-201. doi: 10.1111/j.1472765X.1992.tb00762.x

Ferguson, S., Roberts, C., Handy, E., and Sharma, M. (2013). Lytic bacteriophages reduce Escherichia coli $\mathrm{O} 157: \mathrm{H} 7$ on fresh-cut lettuce introduced through cross-contamination. Bacteriophage 3:e24323. doi: 10.4161/bac t. 24323

Foschino, R., Perrone, F., and Galli, A. (1995). Characterization of two virulent Lactobacillus fermentum bacteriophages isolated from sour dough. J. Appl. Microbiol. 79, 677-683.

Garcia-Doval, C., and van Raaij, M. J. (2012). Structure of the receptor-binding carboxyl-terminal domain of bacteriophage T7 tail fibers. Proc. Natl. Acad. Sci. U.S.A. 109, 9390-9395. doi: 10.1073/pnas.1119719109

Glass, K. A., Loeffelholz, J. M., Ford, J. P., and Doyle, M. P. (1992). Fate of Escherichia coli $\mathrm{O} 157: \mathrm{H} 7$ as affected by $\mathrm{pH}$ or sodium chloride and in fermented, dry sausage. Appl. Environ. Microbiol. 58, 2513-2516.

Griffin, P. M., Bell, B. P., Cieslak, P. R., Tuttle, J., Barrett, T. J., Doyle, M. P., et al. (1994). "Large outbreak of Escherichia coli O157:H7 infections in the western United States: the big picture," in Recent Advances in Verocytotoxin-Producing Escherichia coli Infections, eds M. A. Karmali and A. G. Goglio (New York: Elsevier Science Publishing), 7-12.

Griffin, P. M., and Tauxe, R. V. (1991). The epidemiology of infections caused by Escherichia coli O157:H7, other enterohemorrhagic E. coli and the associated hemolytic uremic syndrome. Epidemiol. Rev. 13, 60-98.

Guenther, S., Huwyler, D., Richard, S., and Loessner, M. J. (2009). Virulent bacteriophage for efficient biocontrol of Listeria monocytogenes in ready-to-eat foods. Appl. Environ. Microbiol. 75, 93-100. doi: 10.1128/AEM.01711-08

Gyles, C. L. (2007). Shiga toxin-producing Escherichia coli: an overview. J. Anim Sci. 85(E. Suppl. ), E45-E62.

Hagens, S., and Loessner, M. J. (2010). Bacteriophage for biocontrol of foodborne pathogens: calculations and considerations. Curr. Pharm. Biotechnol. 11, 58-68. doi: 10.2174/138920110790725429

Hashemolhosseini, S., Holmes, Z., Mutschler, B., and Henning, U. (1994). Alterations of receptor specificities of coliphages of the T2 family. J. Mol. Biol. 240, 105-110. doi: 10.1006/jmbi.1994.1424

Hilborn, E. D., Mshar, P. A., Fiorentino, T. R., Dembek, Z. F., Barrett, T. J., Howard, R. T., et al. (2000). An outbreak of Escherichia coli O157:H7 infections and haemolytic uraemic syndrome associated with consumption of unpasteurized apple cider. Epidemiol. Infect. 124, 31-36. doi: 10.1017/S09502688990 03258

Hill, C. (1993). Bacteriophage and bacteriophage resistance in lactic acid bacteria. FEMS Microbiol. Rev. 12, 87-108. doi: 10.1111/j.1574-6976.1993.tb00013.x
Jinneman, K. C., Yoshitomi, K. J., and Weagant, S. D. (2003). Multiplex real-time PCR method to identify shiga toxins, stx1 and stx2 and E. coli O157:H7 Serogroup. Appl. Environ. Microbiol. 69, 6327-6333. doi: 10.1128/AEM.69.10.63276333.2003

Jordan, K. N., Oxford, L., and O'Byrne, C. P. (1999). Survival of low-pH stress by Escherichia coli O157:H7: correlation between alterations in the cell envelope and increased acid tolerance. Appl. Environ. Microbiol. 65, 3048-3055.

Karmali, M. A. (1989). Infection by verotoxin-producing Escherichia coli. Clin. Microbiol. Rev. 2, 15-38.

Kudva, I. T., Jelacic, S., Tarr, P. I., Youderian, P., and Hovde, C. J. (1999). Biocontrol of Escherichia coli $\mathrm{O} 157$ with O157-specific bacteriophages. Appl. Environ. Microbiol. 65, 3767-3773.

Large, T. M., Walk, S. T., and Whittam, T. S. (2005). Variation in acid resistance among shiga toxin-producing clones of pathogenic Escherichia coli. Appl. Environ. Microbiol. 71, 2493-2500. doi: 10.1128/AEM.71.5.2493-250 0.2005

Leiman, P. G., Chipman, P. R., Kostyuchenko, V. A., Mesyanzhinov, V. V., and Rossmann, M. G. (2004). Three-dimensional rearrangement of proteins in the tail of bacteriophage T4 on infection of its host. Cell 118, 419-429. doi: 10.1016/j.cell.2004.07.022

Leuschner, R. G. K., Arendt, E. K., and Hammes, W. P. (1993). Characterization of a virulent Lactobacillus sake phage PWH2. Appl. Microbiol. Biotechnol. 39, 617-621. doi: 10.1007/BF00205063

Leyer, G. J., and Johnson, E. A. (1993). Acid adaptation induces crossprotection against environmental stress in Salmonella typhimurium. Appl. Environ. Microbiol. 59, 1842-1847.

Leyer, G. J., Wang, L. L., and Johnson, E. A. (1995). Acid adaptation of Escherichia coli O157:H7 increases survival in acidic foods. Appl. Environ. Microbiol. 61, 3752-3755.

Lin, J., Smith, M. P., Chapin, K. C., Baik, H. S., Bennett, G. N., and Foster, J. W. (1996). Mechanisms of acid resistance in enterohemorrhagic Escherichia coli. Appl. Environ. Microbiol. 62, 3094-3100.

Lu, Z., Altermann, E., Breidt, F., Predki, P., Fleming, H. P., and Klaenhammer, T. R. (2005). Sequence analysis of the Lactobacillus plantarum bacteriophage JL-1. Gene 348, 45-54. doi: 10.1016/j.gene.2004.12.052

Lu, Z., Breidt, F., Fleming, H. P., Altermann, E., and Klaenhammer, T. R. (2003). Isolation and characterization of a Lactobacillus plantarum bacteriophage JL1 from a cucumber fermentation. Int. J. Food Microbiol. 84, 225-235. doi: 10.1016/S0168-1605(03)00111-9

Mahony, J., McAuliffe, O., Ross, R. P., and van Sinderen, D. (2011). Bacteriophages as biocontrol agents of food pathogens. Curr. Opin. Biotechnol. 22, 157-163. doi: 10.1016/j.copbio.2010.10.008

Mead, P. S., and Griffin, P. M. (1998). Escherichia coli O157:H7. Lancet 352, 12071212. doi: 10.1016/S0140-6736(98)01267-7

Mead, P. S., Slutsker, L., Dietz, V., McCaig, L. F., Bresee, J. S., Shapiro, C., et al. (1999). Food-related illness and death in the United States. Emerg. Infect. Dis. 5, 607-625. doi: 10.3201/eid0505.990502

Mizoguchi, K., Morita, M., Fischer, C. R., Yoichi, M., Tanji, Y., and Unno, H. (2003). Coevolution of bacteriophage PP01 and Escherichia coli O157:H7 in continuous culture. Appl. Environ. Microbiol. 69, 170-176. doi: 10.1128/AEM.69.1.170176.2003

Morita, M., Tanji, Y., Mizoguchi, K., Akitsu, T., Kijima, N., and Unno, H. (2002). Characterization of a virulent bacteriophage specific for Escherichia coli O157:H7 and analysis of its cellular receptor and two tail fiber genes. FEMS Microbiol. Lett. 211, 77-83. doi: 10.1111/j.1574-6968.2002.tb11206.x

Nataro, J. P., and Kaper, J. B. (1998). Diarrheagenic Escherichia coli. Clin. Microbiol. Rev. 11, 142-201.

Nechaev, S., and Severinov, K. (2008). The elusive object of desire - interactions of bacteriophages and their hosts. Curr. Opin. Microbiol. 11, 186-193. doi: 10.1016/j.mib.2008.02.009

O'Flaherty, S., Ross, R. P., and Coffey, A. (2009). Bacteriophage and their lysins for elimination of infectious bacteria. FEMS Microbiol. Rev. 33, 801-819. doi: 10.1111/j.1574-6976.2009.00176.x

O'Flynn, G., Ross, R. P., Fitzgerald, G. F., and Coffey, A. (2004). Evaluation of a cocktail of three bacteriophages for biocontrol of Escherichia coli O157:H7. Appl. Environ. Microbiol. 70, 3417-3424. doi: 10.1128/AEM.70.6.3417-3424.2004

Ongeng, D., Muyanja, C., Ryckeboer, J., Geeraerd, A. H., Springael, D., and Mauriello, G. (2013). Fate of Escherichia coli O157:H7 and Salmonella enterica in the 
manure-amended soil-plant ecosystem of fresh vegetable crops: a review. Crit. Rev. Microbiol. doi: 10.3109/1040841X.2013.829415 [Epub ahead of print].

Park, M., Lee, J. H., Shin, H., Kim, M., Choi, J., Kang, D. H., et al. (2012). Characterization and comparative genomic analysis of a novel bacteriophage, SFP10, simultaneously inhibiting both Salmonella enterica and Escherichia coli O157:H7. Appl. Environ. Microbiol. 78, 58-69. doi: 10.1128/AEM.06231-11

Price, S. B., Cheng, C. M., Kasper, C. W., Wright, J. C., DeGraves, F. J., Penfound, T. A., et al. (2000). Role of rpoS in acid resistance and fecal shedding of Escherichia coli O157:H7. Appl. Environ. Microbiol. 66, 632-637. doi: 10.1128/AEM.66.2.632637.2000

Price, S. B., Wright, J. C., DeGraves, F. J., Castanie-Cornet, M. P., and Foster, J. W. (2004). Acid resistance systems required for survival of Escherichia coli O157:H7 in the bovine gastrointestinal tract and in apple cider are different. Appl. Environ. Microbiol. 70, 4792-4799. doi: 10.1128/AEM.70.8.4792-4799.2004

Rangel, J. M., Sparling, P. H., Crowe, C., Griffin, P. M., and Swerdlow, D. L. (2005). Epidemiology of Escherichia coli O157:H7 outbreaks, United States, 1982-2002. Emerg. Infect. Dis. 11, 603-609. doi: 10.3201/eid1104.040739

Raya, R. R., Varey, P., Oot, R. A., Dyen, M. R., Callaway, T. R., Edrington, T. S., et al. (2006). Isolation and characterization of a new T-even bacteriophage, CEV1, and determination of its potential to reduce Escherichia coli O157:H7 levels in sheep. Appl. Environ. Microbiol. 72, 6405-6410. doi: 10.1128/AEM.03011-05

Remis, R. S., McDonald, K. L., Riley, L. W., Puhr, N. D., Wells, J. G., Davis, B. R., et al. (1984). Sporadic cases of hemorrhagic colitis associated with Escherichia col O157:H7. Annu. Intern. Med. 101, 728-742. doi: 10.7326/0003-4819-101-5-624

Riede, I. (1987). Receptor specificity of the short tail fibres (gp12) of T-even type Escherichia coli phages. Mol. Gen. Genet. 206, 110-115. doi: 10.1007/BF00326544

Riley, L. W., Remis, R. S., Helgerson, S. D., McGee, H. B., Wells, J. G., Davis, B. R., et al. (1983). Hemorrhagic colitis associated with a rare Escherichia coli serotype O157:H7. N. Engl. J. Med. 308, 681-685. doi: 10.1056/NEJM198303243081203

Santos, S. B., Kropinski, A. M., Ceyssens, P. J., Ackermann, H. W., Villegas, A., Lavigne, R., et al. (2011). Genomic and proteomic characterization of the broadhost-range Salmonella phage PVP-SE1: creation of a new phage genus. J. Virol. 85, 11265-11273. doi: 10.1128/JVI.01769-10

Shahrbabak, S. S., Khodabandehlou, Z., Shahverdi, A. R., Skurnik, M., Ackermann, H. W., Varjosalo, M., et al. (2013). Isolation, characterization and complete genome sequence of PhaxI: a phage of Escherichia coli O157: H7. Microbiology 159, 1629-1638. doi: 10.1099/mic.0.063776-0

Sharma, M. (2013). Lytic bacteriophages: potential interventions against enteric bacterial pathogens on produce. Bacteriophage 3, e25518. doi: 10.4161/bact.25518

Sharma, M., Patel, J. R., Conway, W. S., Ferguson, S., and Sulakvelidze, A. (2009). Effectiveness of bacteriophages in reducing Escherichia coli O157:H7 on fresh-cut cantaloupes and lettuces. J. Food Protien 72, 1481-1485.

Sheng, H., Knecht H. J., Kudva I. T., and Hovde, C. J. (2006). Application of bacteriophages to control intestinal Escherichia coli O157:H7 levels in ruminants. Appl. Environ. Microbiol. 72, 5359-5366. doi: 10.1128/AEM.00099-06

Sheng, H., Lim, J. Y., Watkins, M. K., Minnich, S. A., and Hovde, C. J. (2008). Characterization of an Escherichia coli O157:H7 O-antigen deletion mutant and effect of the deletion on bacterial persistence in the mouse intestine and colonization at the bovine terminal rectal mucosa. Appl. Environ. Microbiol. 74, 5015-5022. doi: 10.1128/AEM.00743-08
Swerdlow, D. L., Woodruff, B. A., Brady, R. C., Griffin, P. M., Tippen, S., Donnell, H. D., et al. (1992). A waterborne outbreak in Missouri of Escherichia coli O157:H7 associated with bloody diarrhea and death. Annu. Intern. Med. 117, 812-819. doi: 10.7326/0003-4819-117-10-812

Tanji, Y., Shimada, T., Yoichi, M., Miyanaga, K., Hori, K., and Unno, H. (2004). Toward rational control of Escherichia coli O157:H7 by a phage cocktail. Appl. Microbiol. Biotechnol. 64, 270-274. doi: 10.1007/s00253-003-1438-9

Tarr, P. I. (1995). Escherichia coli O157:H7: clinical, diagnostic, and epidemiological aspects of human infection. Clin. Infect. Dis. 20, 1-10. doi: 10.1093/clinids/20.1.1 Tomat, D., Migliore, L., Aquili, V., Quiberoni, A., and Balague, C. (2013). Phage biocontrol of enteropathogenic and shiga toxin-producing Escherichia coli in meat products. Front. Cell. Infect. Microbiol. 3:20. doi: 10.3389/fcimb.2013.00020

Topley, W. W. C., and Wilson, G. S. (1990). Principles of Bacteriology, Virology and Immunity. London: B. C. Decker Publisher.

Tuttle, J., Gomez, T., Doyle, M. P., Wells, J. G., Zhao, T., Tauxe, R. V., et al. (1999). Lessons from a large outbreak of Escherichia coli O157:H7 infections: insights into the infectious dose and method of widespread contamination of hamburger patties. Epidemiol. Infect. 122, 185-192. doi: 10.1017/S0950268898001976

Vasu, K., and Nagaraja, V. (2013). Diverse functions of restriction-modification systems in addition to cellular defense. Microbiol. Mol. Biol. Rev. 77, 53-72. doi: 10.1128/MMBR.00044-12

Viazis, S., Akhtar, M., Feirtag, J., and Diez-Gonzalez, F. (2011). Reduction of Escherichia coli O157:H7 viability on leafy green vegetables by treatment with a bacteriophage mixture and trans-cinnamaldehyde. Food Microbiol. 28, 149-157. doi: 10.1016/j.fm.2010.09.009

Weagant, S. D., Bryant, J. L., and Bark, D. H. (1994). Survival of Escherichia coli O157:H7 in mayonnaise and mayonnaise-based sauces at room and refrigerated temperatures. J. Food Protein 57, 629-631.

Yu, S. L., Ko, K. L., Chen, C. S., Chang, Y. C., and Syu, W. J. (2000). Characterization of the distal tail fiber locus and determination of the receptor for phage AR1, which specifically infects Escherichia coli O157:H7. J. Bacteriol. 182, 5962-5968. doi: 10.1128/JB.182.21.5962-5968.2000

Conflict of Interest Statement: The authors declare that the research was conducted in the absence of any commercial or financial relationships that could be construed as a potential conflict of interest.

Received: 10 December 2014; accepted: 20 January 2015; published online: 17 February 2015.

Citation: Lu Z and Breidt F (2015) Escherichia coli O157:H7 bacteriophage $\Phi 241$ isolated from an industrial cucumber fermentation at high acidity and salinity. Front. Microbiol. 6:67. doi: 10.3389/fmicb.2015.00067

This article was submitted to Food Microbiology, a section of the journal Frontiers in Microbiology.

Copyright (C) $2015 \mathrm{Lu}$ and Breidt. This is an open-access article distributed under the terms of the Creative Commons Attribution License (CC BY). The use, distribution or reproduction in other forums is permitted, provided the original author(s) or licensor are credited and that the original publication in this journal is cited, in accordance with accepted academic practice. No use, distribution or reproduction is permitted which does not comply with these terms. 